\title{
Archipelag Senkaku. Źródto napięć na Morzu Wschodniochińskim
}

\section{WPROWADZENIE}

O pory międzynarodowe są ElEMENTEM stosunków między państwami. Rodzą się one niezależnie od epoki historycznej i przestrzeni geograficznej. Obecnie występuje tendencja do rozstrzygania ich metodami pokojowymi. Spośród wielu sporów toczących się na kontynencie azjatyckim zatarg terytorialny między Chinami a Japonią jest szczególnie interesujący, tym bardziej, że nie został on spopularyzowany w polskiej literaturze przedmiotu. Niezwykle przydatne okazują się być źródła zamieszczone na stronach internetowych instytucji rządowych państw zaangażowanych w spór. Tego rodzaju źródła wymagają szczególnej ostrożności i dużej dozy krytycyzmu, gdyż są wytwarzane przez strony konfliktu.

Uwzględniając wpływ tego zatargu na całokształt stosunków chińsko-japońskich, trudno nie zauważyć, że może on w znaczący sposób zdestabilizować sytuację nie tylko w regionie Dalekiego Wschodu. Poprzez złożoną sieć powiązań międzynarodowych incydenty na Morzu Wschodniochińskim mogą wpłynąc na globalną sytuację polityczną.

Poniższy artykuł ma przyczynić się do określenia wpływu wznowionej niedawno niejasnej gry dyplomatycznej między Japonią i Chinami na kształt stosunków bilateralnych między tymi azjatyckimi mocarstwami. Dla zobrazowania problemu za konieczne uznano zaprezentowanie: charakterystyki przedmiotu sporu - wysp Senkaku, jego genezy, stanowisk stron, jego przebiegu, zaognienia na tle wydarzeń z września 2010 r. oraz perspektyw rozwoju sytuacji.

\section{PRZEDMIOT SPORU}

PRZEDMIOTEM SPORU JEST OSIEM MAŁYCH POZORNIE BEZWARTOŚCIOWYCH WYSEPEK zlokalizowanych na Morzu Wschodniochińskim pomiędzy Tajwanem a Okinawą. Łączna powierzchnia wysp wynosi zaledwie 
$7 \mathrm{~km}^{21}$. Wyspy te nie tylko są niezamieszkałe, lecz także z uwagi na brak wody pitnej nie stanowią nawet atrakcyjnego obszaru do zaludniania. W rzeczywistości jednak ze względu na odkryte w ich okolicach bogate złoża ropy naftowej i gazu ziemnego mogą dla obu państw mieć znaczenie strategiczne. W literaturze przedmiotu podkreśla się również wartość Morza Wschodniochińskiego dla rozwoju rybołówstwa ${ }^{2}$. Należy jednak podkreślić, że dla kształtowania się sporu argument ten nie ma większego znaczenia.

W powszechnym użyciu stosowana jest nazwa japońska Sento Shosho lub Senkaku Retto. Można jednak doszukać się źródeł wskazujących na nazwę chińską Diaoyu Tai, a nawet transkrypcję używaną na Tajwanie - Tiao Yu Ta'i ${ }^{3}$. Dla potrzeb niniejszej pracy zastosowanie znalazła nazwa japońska z przynajmniej dwóch powodów. Po pierwsze jest najpopularniejsza w materiałach źródłowych, a po drugie wyspy znajdują się pod japońską administracją.

\section{GENEZA SPORU}

Początek Sporu o ARChipelag Senkaku sięga przełomu lat 60. i 70. XX w. Wiąże się on z badaniami wskazującymi na lokalizację bogatych złóż surowców w rejonie Morza Wschodniochińskiego. W 1969 roku został opracowany raport Komisji Gospodarczej ONZ dla Azji i Dalekiego Wschodu. Potwierdzał on występowanie ropy naftowej i gazu ziemnego w rejonie Senkaku. Podobne wyniki przyniosły analizy Rand Corporation ${ }^{4}$. Można zatem uznać, że to rezultaty badań przyczyniły się do powstania sporu. Aby zobrazować tę tezę należy nieco szerzej przedstawić reakcję stron.

Od grudnia 1969 r. toczyły się negocjacje między Japonią a Stanami Zjednoczonymi w sprawie przywrócenia administracji japońskiej terytoriów okupowanych przez Stany Zjednoczone po drugiej wojnie światowej (archipelag Riuku). Negocjacje sprowokowały chińską reakcję. Jako pierwsza zaprotestowała Republika Chińska na Tajwanie. Reakcja Tajwanu miała miejsce już w sierpniu 1970 r., podczas gdy

${ }^{1}$ K. Kubiak, W. Kustra, Zatargi o archipelagi na Morzu Wschodniochińskim i Morzu Japońskim jako przykłady współczesnych sporów terytorialnych $w$ obrębie obszarów morskich, „Zeszyty Naukowe Akademii Marynarki Wojennej” 2005, nr 1 (160), s. 57.

2 Zob. J. Rowiński, Spory graniczne i konflikty terytorialne $w$ Azji Wschodniej u progu XXI w., [w:] Azja Wschodnia na przetomie XX i XXI wieku. Stosunki międzynarodowe i gospodarcze, red. K. Gawlikowski, Warszawa 2004, s. 129.

${ }^{3}$ K. Kubiak, W. Kustra, Zatargi o archipelag..., op. cit., s. 57.

${ }_{4}^{4}$ Zob. J. Rowiński, Spory graniczne..., op. cit., 129. 
ChRL wyraziła swoje stanowisko dopiero w oświadczeniu ministerstwa spraw zagranicznych z 30 grudnia 1971 r. ${ }^{5}$. Stwierdzono wówczas, iż wyspy Senkaku stanowią, podobnie jak Tajwan, część terytorium ChRL. Jednak ze względu na postępujący proces normalizacji stosunków chińsko-japońskich oraz brak dokładnych danych co do wielkości zlokalizowanych w rejonach wysp zasobów, były one traktowane jako sprawa drugorzędna ${ }^{6}$.

\section{STANOWISKA STRON SPORU}

Stanowisko Chińskiej Republiki LudoweJ bazuje na uznaniu historycznej przynależności wysp do Chin. Wskazuje się na fakt ich odkrycia już w 1372 roku przez chińskich żeglarzy. Stanowiły one punkt nawigacyjny na szlaku morskim prowadzącym na Okinawę, skąd Chiny odbierały trybut. Wyspy wchodziły w skład obszaru obrony morskiej Cesarstwa Chińskiego. Zostały przejęte przez Japonię pod koniec XIX (1895 r.) na mocy traktatu z Shimonsheki, kończącego rywalizację tych państw o wpływy na Półwyspie Koreańskim7. ChRL utrzymuje również, że wyspy stanowią obszar terytorialny Tajwanu (traktowanego jako „zbuntowana prowincja” Chin).

Stanowisko Republiki Chińskiej pod względem historycznym jest zbieżne z linią prezentowaną przez ChRL. Zasadnicza różnica polega jednak na kwestii prawno-międzynarodowego uznania Republiki Chińskiej ${ }^{8}$. Tajwan powołuje się również na czynniki geologiczne, twierdząc, że wyspy stanową naturalne przedłużenie jego terytorium. Jednak z uwagi na swój ograniczony potencjał oraz prawno-międzynarodowy status odgrywa on w sporze rolę marginalną.

Stanowisko Japonii również opiera swoje stanowisko na bogatej argumentacji. Twierdzi się, że rejon wysp został uznany jako terra nullius (ziemia niczyja) w latach 80 . XIX wieku i ich zajęcie nie miało wcale związku z ekspansjonizmem. W trakcie prowadzonych w II poł. XIX w. badań, japońskim instytucjom udało się ustalić, że Senakaku

${ }_{5}$ M. Łuszczuk, Stosunki chińsko-japońskie, [w:] Chiny w stosunkach międzynarodowych, red. K. Iwańczuk, A. Ziętek, Lublin 2003, s. 163.

${ }^{6}$ Ibidem.

${ }^{7}$ J. Rowiński, Spory graniczne..., op. cit., s. 129; W. B. Helfin, Diayou/Senkaku Islands Dispute: Japan and China, Oceans Apart, Asian-Pacific Law \& Policy Journal, http://www.hawaii.edu/aplpj/articles/APLPJ_01.2_heflin.pdf, 3.12.2010 r.

${ }^{8}$ W Republice Chińskiej swoje ambasady utrzymuje 19 państw, które nie odgrywają jednak istotnej roli w stosunkach międzynarodowych. Zob. Foreign Embassies in the ROC (Taiwan), http://www.mofa.gov.tw/webapp/lp.asp?CtNode $=1867 \&$ CtUnit $=34 \& B$ aseDSD $=32 \& \mathrm{mp}=6 \&$ nowPage $=1 \&$ pagesize $=15,14.04 .2011 \mathrm{r}$. 
nie stanowiło części terytorium Chin. Uważa się, że wyspy nie tylko nie stanowią terytorium chińskiego, lecz są przedłużeniem archipelagu Riuku. Utrzymuje się również, że nie stanowiły one ani części Tajwanu, ani Peskadorów, czyli terytoriów przekazanych przez Chiny Japonii na mocy traktatu z Shimonosheki ${ }^{10}$.

\section{INTERPRETACJA ZAPISÓW PRAWA MIĘDZYNARODOWEGO}

WYSOCE PROBLEMATYCZNE JEST WYJAŚNIENIE WĄTPLIWOŚCI powstałych na tle interpretacji prawa międzynarodowego. Aby uchwycić te trudności, należy odwołać się do wspominanego wcześniej traktatu z Shimonoseki, traktatu z San Francisco, traktatu pomiędzy Japonią a Tajwanem oraz deklaracji kairskiej.

W pierwszym z analizowanych aktów prawnych tj. traktacie z Shimonoseki (podpisanym 17 kwietnia 1895 r.), pojawiły się regulacje dotyczące przyznania Japonii przez Chiny części ich terytorium. Artykuł drugi traktatu wskazuje, że: „Chiny cedują na rzecz Japonii wieczną i pełną suwerenność na następującymi terytoriami łącznie z fortyfikacjami, arsenałami, publiczną własnością: (...) Wyspą Formoza wraz z wszystkimi wyspami przyległymi, lub przynależnymi do Formozy"11. Problem wynikający z interpretacji tego traktatu polega na tym, iż nie wymienia on wprost nazw wysp. Nie wiadomo zatem, czy dotyczy on archipelagu Senkaku.

Kolejnym dokumentem odwołującym się do terytoriów uzyskanych przez Japonię był tzw. komunikat kairski z roku 1943. Prezydent Stanów Zjednoczonych Franklin Delano Roosevelt, premier Wielkiej Brytanii Winston Churchill oraz przywódca Chin Czang Kai-szek podjęli się rozstrzygnięcia tych kwestii: „Trzech wielkich sprzymierzeńców toczy tę wojnę o powstrzymanie i ukaranie agresji Japonii. Nie pragną oni korzyści dla siebie i nie dążą do ekspansji terytorialnej. Ich celem jest odebranie wszystkich wysp na Pacyfiku, które zajęła, lub okupowała Japonia od początku pierwszej wojny światowej w 1914 i wszystkich terytoriów skradzionych Chinom przez Japonię, takich jak Mandżuria, Formoza i Peskadory, będą one zwrócone Republice Chińskiej”"2.

${ }^{9}$ The Basic View on the Sovereignty over the Senkaku Islands, http://www.mofa. go.jp/region/asia-paci/senkaku/senkaku.html, 13.04.2011 r.

${ }^{10} \mathrm{~K}$. Kubiak, W. Kustra, Zatargi o archipelag..., op. cit., s. 58.

${ }^{11}$ Treaty of Shimonoseki Signed at Shimonoseki, 17 April 1895, http://www.taiwandocuments.org/shimonosekio1.htm [tłumaczenie własne], 14.04.2011 r.

${ }_{12}$ Cairo Communiqué, http://www.ndl.go.jp/constitution/e/shir-o/o1/oo2_46 /o02_46tx.html, [tłumaczenie własne], 20.04.2011 r. 
Także traktat z San Francisco bezpośrednio nie odnosił się do wysp Senakaku. Sprawa zwrotu terytoriów odebranych przez Japonię Chinom została poruszona w artykule drugim i trzecim. Mowa tam m.in. o zrzeczeniu się przez Japonię pretensji do Formozy i Peskadorów oraz wysp Spratly i Paraceli ${ }^{13}$. W artykule trzecim niniejszego traktatu wskazano z kolei na przekazanie po amerykańską administrację archipelagów Riuku i Daito, z których wcześniej była sprawowana kontrola nad wyspami ${ }^{14}$. Żadne z państw chińskich jednak nie podpisało traktatu z San Francisco. Istotne znaczenie ma traktat pokojowy między Republiką Chińską a Japonią. Artykuł drugi potwierdza postanowienia traktatu pokojowego z San Francisco ${ }^{15}$. W jego artykule trzecim wskazano, że regulacja statusu wysp odebranych Chinom stanie się przedmiotem specjalnego porozumienia między Japonią a Tajwanem ${ }^{16}$.

Zarówno oba państwa chińskie, jak i Japonia odmiennie interpretują zapisy poszczególnych układów. Obie strony w swojej argumentacji pomijają niewygodne dla nich fakty lub starają się nimi manipulować. Japonia, wychodząc z założenia, że problem zwierzchnictwa nad Senkaku nie został poruszony ani przez traktat z Shimonosheki, ani przez inne wspomniane traktaty i deklaracje, dowodzi, że ich przynależność do niej nie powinna budzić wątpliwości. W rzeczywistości nie da się jednak ukryć, że uzyskanie wysp stało się efektem podboju militarnego. Mimo to Japonia zaprzecza, że zajęcie Senkaku było skutkiem rozwijającego się pod koniec XIX wieku ekspansywnego nacjonalizmu. Uważa się także, że w świetle prawa międzynarodowego chińskie roszczenia do wysp o podłożu historycznym, geologicznym, czy geograficznym nie mają uzasadnienia ${ }^{17}$.

Z kolei pewne wątpliwości może budzić fakt zainteresowania się sprawą wysp przez oba państwa chińskie dopiero na przełomie lat 60. i 70. XX w. Przez kilkadziesiąt lat od zakończenia drugiej wojny światowej ani ChRL, ani Tajwan nie podjęły żadnego kroku celem odzyskania władztwa nad nimi ${ }^{18}$. Innym, dość poważnym mankamentem jest kwestia reprezentacji narodu chińskiego. Mimo iż, od początku lat 70. Chińska Republika Ludowa zajmuje miejsce Republiki Chińskiej

13 Treaty of Peace with Japan Signed at San Francisco, 8 September 1951, http://www.taiwandocuments.org/sanfrancisco01.htm, 20.04.2011 r.

${ }^{14}$ Ibidem. Por. K. Kubiak, W. Kustra, Zatargi o archipelag ...,, op. cit., s. 59.

${ }_{15}$ Treaty of Peace between the Republic of China and Japan, Signed at Taipei, 28 April 1952, http://www.taiwandocuments.org/taipeio1.htm, 20.04.2011 r.

${ }^{16}$ Ibidem.

${ }^{17}$ The Basic View..., op. cit.

${ }^{18}$ J. Rowiński, Spory graniczne..., op. cit., s. 129. 
w ONZ, to Republika Chińska konsekwentnie uważa się za przedstawiciela narodu chińskiego. Wobec powyższych ustaleń łatwo dowieść, że stronom, które powołują się na rozmaitą argumentację (zwłaszcza prawo-międzynarodową), negującą racje innego zaangażowanego państwa, trudno dojść do jakiegokolwiek kompromisu, tym bardziej, że w grę wchodzą sprzeczne interesy.

\section{PRZEBIEg SPORU}

W LATACH SIEDEMDZIESIĄTYCH SPÓR NIE ODGRYWAE WIĘKSZEGO ZNACZENIA w stosunkach chińsko-japońskich. Doszło wówczas do normalizacji stosunków pomiędzy ChRL a Japonią. Potwierdzeniem tego jest traktat o Pokoju i Przyjaźni. Deng Xiaoping w 1978 r. stwierdzil, że wyspy nie powinny stanowić przedmiotu sporu: „Nasze pokolenie okazało się niedostatecznie mądre, aby znaleźć rozwiązanie tego problemu, pozostawmy więc go naszym następcom"19. Miało wówczas miejsce kilka incydentów, nie prowadziły one jednak do większych nieporozumieńn ${ }^{20}$. Również w latach osiemdziesiątych temat wysp był na dalszym planie wzajemnych stosunków. Do zaognienia sytuacji dochodziło stopniowo m.in. za sprawą pobudzenia nastrojów nacjonalistycznych w latach dziewięćdziesiątych.

W 1992 r. Ogólnochińskie Zgromadzenie Przedstawicieli Ludowych przyjęło ustawę o morzu terytorialnym i strefie przyległej. $\mathrm{W}$ artykule drugim tej ustawy jest o mowa m.in. o statusie terytorium lądowego, obejmującego ląd stały i terytoria przybrzeżne, w tym również wyspy Diaoyu i inne, które należą do Chińskiej Republiki Ludowej $^{21}$. Ustawa dawała prawo rządowi do podjęcia zdecydowanych działań celem objęcia panowania nad spornymi wyspami, co zostało oprotestowane przez Japonię ${ }^{22}$.

${ }^{19}$ Cyt. za: M. Wangrat, Spór Chin i Japonii o Archipelag Senkaku, [w:] Wspótczesny Daleki Wschód w stosunkach międzynarodowych - rywalizacja i mocarstwowość, red. D. K. Gemechu, Olsztyn 2008, s. 212.

20 Wiele kontrowersji wzbudziła prowokacja Chin w 1978r. Kilka uzbrojonych okrętów chińskich dopłynęło wówczas do spornego archipelagu. Według komentatorów celem tego zabiegu miało jednak wymuszenie na Japonii ustępstw w negocjowanym traktacie o Pokoju i Przyjaźni. Zob. E. Dryjańska, Gtówne problemy w stosunkach Chińskiej Republiki Ludowej z Japonią, [w:] Wspótczesny Daleki Wschód ..., op. cit., s. 195.

${ }^{21}$ Law on the Territorial Sea and the Contiguous Zone of 25 February 1992, http:// www.un.org/Depts/los/LEGISLATIONANDTREATIES/PDFFILES/CHN_1992_Law. pdf, 01.06.2011 r.

${ }^{22}$ R. Weitz, Dlaczego japońsko-chińska kłótnia szkodzi im obu, http://www.stosunkimiedzynarodowe.info/artykul,788,Dlaczego_japonsko-chinska_klotnia_sz- 
W latach 90. dochodziło do kilku groźnych incydentów za sprawą m.in. japońskich organizacji nacjonalistycznych. Spośród nich szczególną aktywnością wsławiła się Młoda Japonia. W 1996 r. wzniosła ona na jednej z wysp latarnię morską. W odpowiedzi chińscy nacjonaliści przedostali się na wyspy i wywiesili chińskie flagi. Dwa lata później członkowie Młodej Japonii dopuścili się podobnej prowokacji ${ }^{23}$.

Dostrzegając powagę sytuacji, rządy Japonii i Chin podjęły się próby poszukania rozwiązania zadowalającego obie strony. Równocześnie zarówno Chiny, jak i Japonia przymierzały się do eksploatacji surowców. Trwające w latach 2004-2008 negocjacje, mimo zapowiadanego przełomu, nie przyczyniły się do zasadniczego uregulowania sporu. Co więcej w ubiegłej dekadzie doszło do poważnego pogorszenia stosunków między państwami. Powodów do napięć nie brakowało m.in. za sprawą polityki premiera japońskiego rządu Junichiro Koizumiego.

Konserwatywne sympatie japońskiego premiera nie sprzyjały dialogowi, tym bardziej, że był on oskarżany o wizyty w świątyni Yasukuni, gdzie czczono japońskich żołnierzy, nawet tych uznawanych za zbrodniarzy wojennych. Ostentacyjnie czołowi chińscy politycy unikali podróży do swojego morskiego sąsiada. W tym czasie miały miejsce również inne wydarzenia wpływające na kształt wzajemnych stosunków. W 2004 r. chińskie statki badawcze i okręty wojskowe wpłynęły na wody uznawane za Wyłączną Strefę Ekonomiczną Japonii ${ }^{24}$. W 2006 i 2007 r. doszło do podobnych incydentów na Morzu Wschodniochińskim. Do znaczącego ochłodzenia przyczyniły się również zmiany w treści japońskich podręczników bagatelizujące zbrodnie popełnione przez Japończykach na ludności chińskiej podczas wojny w latach 1937-1945.

\section{INCYDENT Z 7 WRZEŚNIA 2010 R. ORAZ JEGO KONSEKWENCJE}

PO KRÓTKIM OKRESIE WZGLĘDNEGO SPOKOJU na Morzu Wschodniochińskim doszło do incydentu, który znacznie pogorszył relacje między Chinami a Japonią ${ }^{25} .7$ września 2010 r. miała miejsce kolizja chińskiego kutra rybackiego z dwoma japońskimi okrętami straży przybrzeżnej. Incydent wywołał szereg następstw. Służby japońskie aresztowały załogę statku, co z kolei wywołały oficjalny protest przedstawicieli ChRL skie-

\footnotetext{
kodzi_im_obu, 21.04.2011 r.

${ }^{23}$ K. Kubiak, W. Kustra, Zatargi o archipelag..., op. cit., s. 60-61.

${ }^{24}$ E. Dryjańska, Gtówne problemy..., op. cit., s. 197.

${ }^{25}$ Warto mieć na uwadze, że do incydentów w samym 2010 roku dochodziło kilkukrotnie, jednakże nie wpływały zasadniczo na jakość wzajemnych stosunków.
} 
rowany do ambasadora Japonii w Chinach Uichiro Niwy. Rozmowy pomiędzy ambasadorem Japonii a przedstawicielami chińskiego MSZ odbywały się kilkukrotnie. 13 września uwolniono (najprawdopodobniej pod presją przedstawicieli chińskiego MSZ) 14 członków załogi (zwolnienie nie dotyczyło kapitana statku Zhana Qixionga) ${ }^{26}$.

W wyniku incydentu i zatrzymania załogi kutra doszło w Chinach do mobilizacji nacjonalistów. Przed japońską ambasadą w Pekinie odbyły się demonstracje upamiętniające incydent mukdeński inicjujący zaangażowanie militarne Japonii w Mandżurii w latach 30. XX wie$\mathrm{ku}^{27}$. Sam premier chińskiej Rady Państwa Wen Jiabao przebywający wówczas w Nowym Jorku wezwał 21 września Japonię do natychmiastowego i bezwarunkowego uwolnienia kapitana kutra, grożąc zastosowaniem ostrzejszych środków ${ }^{28}$.

Cały cykl zdarzeń doprowadził do sytuacji, w której spór zaczął wychodzić poza sferę dyplomacji. W obawie przed dalszym pogarszaniem się relacji chińsko-japońskich kapitan kutra został zwolniony z aresztu. Reakcją Chin było oświadczenie, które wygłosił minister spraw zagranicznych. Uznał wcześniejsze działania Japonii za bezprawne i bezpodstawne. Żądał przeprosin i rekompensaty za incydent ${ }^{29}$. W odpowiedzi japońskie MSZ zamieściło komunikat, w którym podkreślono japońskie prawa do wysp, żądania chińskie uznano za nie do zaakceptowania oraz podkreślono wagę stosunków japońsko-chińskich dla obydwu państw oraz dla regionu i społeczności międzynarodowej ${ }^{30}$.

${ }^{26}$ Chronologiczny zapis najważniejszych zdarzeń związanych z incydentem znajduje na stronie internetowej japońskiego MSZ w komunikacie Major Exchanges between Japan and the People's Republic of China concerning the Collision Incident between Japan Coast Guard Patrol Vessels and a Chinese Fishing Trawler in Japanese Territorial Waters off the Senkaku Islands, http://www.mofa.go.jp/region/asia-paci/china/rrelations/major_e.html, 29.04.2011 r.

${ }^{27}$ Incydentem mukdeńskim nazwano prowokację armii japońskiej (oddziału kwantuńskiego) z 18 września 1931 r., polegającą na wysadzeniu w powietrze torów kolejowych należących do Japonii i oskarżeniu o to zajście Chin. Incydent stanowił pretekst do ekspansji Japonii na obszar Mandżurii. Zob. J. Fenby, Chiny. Upadek i narodziny wielkiej potęgi, Kraków 2009, s. 334-336.

${ }_{28}$ Por. Japońsko-chiński spór o kolizję koło wysp Senkaku, http://www.stosunkimiedzynarodowe.info/artykul,802,Japonsko-chinski_spor_o_kolizje_kolo_wysp_ Senkaku_?_q_and_a, 21.04.2011 r., Major Exchanges... op. cit., Wen Jiabao Urges Japan to Release Chinese Captain Immediately and Unconditionally, http://www.fmprc. gov.cn/eng/wjb/zzjg/yzs/xwlb/t755599.htm, 13.04.2011 r.

${ }^{29}$ Statement by the Ministry of Foreign Affairs of The People's Republic of China 25 September 2010, http://www.fmprc.gov.cn/eng/zxxx/t755932.htm, 13.04.2011 r..

${ }^{30}$ Statement by the Press Secretary/Director-General for Press and Public Re- 
Upływ czasu przyczynił się do złagodzenia sytuacji i zmniejszenia napięcia. Jednak nadal utrzymywały się silne nastroje nacjonalistyczne. W połowie stycznia $2011 \mathrm{r}$. doszło do wybicia szyb w japońskiej ambasadzie w Pekinie. Sprawcami najprawdopodobniej byli nacjonaliści. W marcu w rejonie wysp pojawiły się też chińskie okręty oraz samoloty, co wywołało zaniepokojenie władz japońskich. Tego rodzaju manifestowanie siły militarnej ma skłonić Japonię do ustępstw na rzecz Chin.

\section{ZNACZENIE SPORU W STOSUNKACH CHIŃSKO-JAPOŃSKICH}

SPÓR O WYSPY SENKAKU POWINIEN BYĆ POSTRZEGANY PRZEZ PRYZMAT całokształtu stosunków chińsko-japońskich. Można nawet pokusić się o twierdzenie, że stan napięcia w ramach rywalizacji o wyspy jest pochodną całokształtu relacji bilateralnych. Podejmując się analizy implikacji sporu warto rozpatrzyć kilka zagadnień: tło historyczne, rozwój gospodarczo-militarny Chin, zapotrzebowanie na surowce energetyczne, postawy nacjonalistyczne, stosunki Japonii z Tajwanem oraz reakcję innych mocarstw zaangażowanych w regionie (przede wszystkich Stanów Zjednoczonych).

Analizując tło historyczne należy pamiętać o wielowiekowej rywalizacji obu państw. Przez długi czas rozwoju wzajemnych stosunków dochodziło do konfliktów pomiędzy nimi. Szczególnie silny jest zakorzeniony w chińskiej świadomości militaryzm japoński z końca XIX wieku oraz ekspansja z lat trzydziestych i czterdziestych XX w. Pamięć o zbrodniach japońskich jest czynnikiem hamującym postęp we wzajemnych stosunkach i na tej podstawie rodzą się nieporozumienia. Warto zauważyć, iż Japonia również nie potrafi jednoznacznie ocenić intencji Chin. Po masakrze na placu Tiananmen polityka Chińskiej Republiki Ludowej została uznana za nieprzewidywalną.

Rozwój gospodarczo-militarny Chin również budzi zaniepokojenie władz japońskich. Świadome wzrastającej roli w świecie Chiny coraz wyraźniej artykułują swoje roszczenia. Pojawia się zatem trudność związana z oceną charakteru chińskiej polityki. Z jednej strony Chiny uważają się za bardziej asertywne (niezależne), z drugiej zaś oskarża się je o zapędy ekspansjonistyczne.

lations, Ministry of Foreign Affairs, on the Collision between Japan Coast Guard Patrol Vessels and a Chinese Fishing Trawler in Japan's Territorial Waters off the Senkaku Islands, September 25, 2010, http://www.mofa.go.jp/announce/announce/2010/9/0925_01.html, 14.04.2011 r. 
W obliczu wzrastających nacjonalizmów występowanie dalszych napięć, m.in. na tle historycznym staje się coraz bardziej prawdopodobne $^{31}$. Wyspy mogą stanowić pretekst do wzajemnych oskarżeń.

Wobec wzrastającego zagrożenia ze strony Chin nie powinna dziwić coraz większa aktywność zwolenników remilitaryzacji. Można doszukać się twierdzeń, że jakiekolwiek ustępstwo wobec Chin będzie stanowiło potwierdzenie słabości Japonii i zachęci Chiny do wysuwania nowych roszczeń terytorialnych.

Przedstawiciele tzw. „frakcji jastrzębi” nalegają na zmianę przepisów konstytucji Japonii zabraniającej jej utrzymywania sił zbrojnych $^{32}$. Obecnie Japonia dysponuje Siłami Samoobrony. W rzeczywistości jednak wartość bojowa jednostek samoobrony jest zbliżona do najlepszych armii świata. W praktyce problem dotyczy więc wyłącznie nazewnictwa. Artykuł 9. staje się zatem przedmiotem dyskusji33. Niewykluczone jest także zaangażowanie się przez Japonię w przyszłości w budowę potencjału nuklearnego. Przy zaawansowanym poziomie rozwoju technologicznego Japonii przystąpienie przez nią do „klubu atomowego" mogłoby nastąpić relatywnie szybko.

${ }^{31}$ Richard Weitz wskazał na ogromny potencjał agitacji antyjapońskiej w Chinach. Zauważył też, że zdaniem obserwatorów antyjapońskie protesty sprzed kilku lat mogły być zaaranżowane przez same władze ChRL. R. Weitz, Dlaczego japońsko-chińska..., op. cit. Władze ChRL starają się hamować tendencje nacjonalistyczne. Radykalizacja nastrojów mogłaby doprowadzić do agresywniejszej polityki zagranicznej, co nie jest zgodne z bieżącymi interesami Chin. Wydaje się, że japoński nacjonalizm ma inny charakter od nacjonalizmu chińskiego, tj. niezależny od władz, natomiast nacjonalizm chiński jest sterowany, czyli zgodny z interesami władz ChRL.

${ }^{32} \mathrm{~W}$ ramach rządzącej przez wiele w Japonii Partii Liberalno-Demokratycznej utworzył się specyficzny podział. Przejawiał się on także w stosunkach japońskochińskich i japońsko-tajwańskich. Frakcja liberalna zajmowała stanowisko zdecydowanie bardziej protajwańskie, niż frakcja konserwatywna. Interesujący artykuł na temat podziałów w Partii Liberalno-Demokratycznej przedstawił Karol Żakowski. Zob. K. Żakowski, Przekonania, a rzeczywistość. Podział Partii Liberalno-Demokratycznej na skrzydto liberalne $i$ konserwatywne, a japońska polityka zagraniczna, [w:] Meandry japońskiej polityki, red. J. Marszałek-Kawa, Toruń 2008.

${ }_{33} \mathrm{~W}$ artykule 9. Konstytucji Japonii znajduje się zapis zabraniający Japonii utrzymywania armii: „Naród japoński, dążąc szczerze do międzynarodowego pokoju partego na sprawiedliwości i porządku, wyrzeka się na zawsze wojny jako suwerennego prawa narodu, jak również użycia lub groźby użycia siły jako środka rozwiązywania sporów międzynarodowych. Dla osiągnięcia celu określonego w poprzednim ustępie nie będą nigdy utrzymywane siły zbrojne lądowe, morskie i powietrzne ani inne środki mogące służyć wojnie. Nie uznaje się prawa państwa do prowadzenia wojny”. Konstytucja Japonii z 3 listopada 1946, http://www.pl.emb-japan.go.jp/relations/konstytucja.htm, 21.04.2011 r., [tłumaczenie prof. Teruji Suzuki]. Zob. też E. Dryjańska, Główne problemy ..., op. cit., s. 185 . 
Równie istotna wydaje się kondycja energetyczna Chin i Japonii. W przypadku Japonii sytuacja jest o wiele bardziej problematyczna. $\mathrm{Z}$ danych opublikowanych przez agencję rządową USA - EIA (Energy Information Administration) wynika, że konsumpcja surowców utrzymuje się od kilku lat na podobnym poziomie - nieznaczenie wzrasta zużycie gazu ziemnego i maleje zużycie ropy naftowej. W strukturze produkcji energii dominuje ropa naftowa (46 proc.), z kolei zużycie gazu ziemnego wynosiło 17 proc. całkowitego zużycia energii ${ }^{34}$. Najbardziej kłopotliwe jest oparcie produkcji energii o surowce pochodzące z importu. Japonia nie ma jednak innej możliwości, gdyż jej własne zasoby są niewystarczające. Wydobycie surowców z Morza Wschodniochińskiego mogłoby poprawić kondycję energetyczną Japonii ${ }^{35}$. Także dla Chin perspektywa uzyskania nowych źródeł surowców jest korzystna. Przy utrzymującym się poziomie wzrostu gospodarczego sięgającym 8-10\% dostępność surowców staje się niezwykle ważna, tym bardziej, że chińską gospodarkę cechuje wysoka energochłonnośćc ${ }^{36}$.

Znaczącą rysę w stosunkach Chiny-Japonia wywołało poparcie Japonii dla Republiki Chińskiej. Władze ChRL wyrażają niezadowolenie z protajwańskiej polityki Japonii. Interesujące jest również to, że Japonia próbowała porozumieć się z Tajwanem w sprawie eksploatacji zasobów w zamian za umożliwienie połowów tajwańskim rybakom w wyznaczonej strefie.

Również interesy Stanów Zjednoczonych są dość poważnie zagrożone. Utrzymując bardzo silne związki z tymi państwami, administracja amerykańska unika jednoznacznego opowiedzenia się po którejś ze stron. Problematyczne jest postępujące uzależnienie gospodarki USA od Chin, przy jednoczesnych zobowiązaniach sojuszniczych wobec Japonii ${ }^{37}$. Przedstawiciele Chin próbowali skłonić Stany Zjed-

34 Dane za rok 2009. Na podstawie: http://www.eia.doe.gov/countries/cab. cfm?fips=JA, 21.04.2011 r.

35 Ustalenie wielkości zasobów zlokalizowanych wokół wysp rodzi trudności. Występuję problemy z dostępnością do wiarygodnych danych. Z kolei przytoczonych przez Richarda Weitza danych wynika, że są one szacowane na około 100 miliardów baryłek ropy naftowej i 7 bilionów stóp sześciennych gazu ziemnego. Zob. R. Weitz, Dlaczego japońsko-chińska..., op. cit.

${ }^{36}$ W odniesieniu do Chin w publicystyce używa się sformułowania „głód surowców”. Wobec wysokiej energochłonności gospodarki władze Chin podejmują działania zmierzające do podniesienia wydajności sektora energetycznego, co ma skutkować min. ograniczeniem zużycia energii na jednostkę PKB.

37 Jeszcze w maju 2010r. rzecznik chińskiego MSZ zapytany o stanowisko Japonii w sprawie Senkaku i dwustronnego traktatu o Wzajemnej Współpracy i Bezpieczeństwie 
noczone do niezajmowania stanowiska w sporze. Podczas spotkania ministra spraw zagranicznych Chin Yang Jiechi z sekretarzem stanu USA Hilary Clinton doszło do rozmowy na temat Wysp Senkaku. Yang nalegał na H. Clinton, by rząd USA zachował ostrożności w związku z wrażliwością Chin na tle suwerenności i integralności terytorialnej ${ }^{38}$. Zachwianie równowagi w Azji Wschodniej może odbić się na polityce Stanów Zjednoczonych w tym regionie.

\section{WNIOSKI}

PodsumowuJĄc POWYŻsZe ustalenia, NALeŻY MIEĆ NA UWADZE nie tylko sytuację w Azji Wschodniej. Konieczne jest odniesienie do kontekstu globalnego. Na bazie uogólnień można formułować pewne scenariusze. Spór jest jednak nieprzewidywalny i trudno o jednoznaczną prognozę. W literaturze przedmiotu wskazuje się, że wraz ze wzrostem zapotrzebowania na surowce energetyczne oraz coraz rzetelniejszymi danymi dotyczącymi zlokalizowanych na Morzu Wschodniochińskim zasobów ryzyko konfrontacji będzie wzrastać. Według pesymistycznych prognoz wzrost nacjonalizmów i rywalizacji pomiędzy państwami może doprowadzić do bezpośredniego starcia. Rozwiązanie takie byłoby jednak skrajnie niekorzystne dla obydwu stron, dlatego też należy je uznać za mało prawdopodobne.

Drugi, bardziej optymistyczny wariant wyklucza możliwość konfliktu zbrojnego. Należy raczej oczekiwać ugody. Strony, dostrzegając korzyści ze wspólnej eksploatacji surowców i idąc na rozwiązanie kompromisowe podejmą współpracę. Nie oznacza to wcale, że porozumienie musi być oparte na obustronnych i równych ustępstwach. Bardzo możliwe, że to Japonia, będąc w uprzywilejowanej sytuacji, skłoni Chiny do zaakceptowania korzystnego dla niej rozwiązania.

Nie ulega wątpliwości, że sporny archipelag ma wpływ na inne płaszczyzny stosunków bilateralnych Chin i Japonii. Jakkolwiek osiągnięcie porozumienia satysfakcjonującego obie strony wydaje się trudne, to jest ono niezbędne, ponieważ brak współpracy tych dwóch wschodnioazjatyckich mocarstw stanowi zagrożenie dla stabilności regionu.

zasugerował, że wyspy są od wieków terytorium chińskim a dwustronne porozumienia Stanów Zjednoczonych i Japonii nie powinny naruszać interesów państw trzecich. Zob. Foreign Ministry Spokesperson Ma Zhaoxu's Response to Japan's Remarks on the Diaoyu Islands, http://www.fmprc.gov.cn/eng/xwfw/s2510/t704771.htm, 13.04.2011, r.

${ }^{38}$ Foreign Minister Yang Jiechi Meets with His U.S. Counterpart Hillary Clinton, http://www.fmprc.gov.cn/eng/zxxx/t765850.htm, 13.04.2011 r. 


\section{Summary}

The article analyzes the question of Senkaku/Diauoyu Islands dispute between Japan, China and Taiwan. The aim of the text is to present how the dispute has affected Japan-China bilateral relations. At first, the paper focuses on characterization: the subject of dispute, claims of countries, its course and an international aspect. The second part considers: the incident in September 2010 and its consequences, the dispute effects and prosperities of its regulations. The relations between China and Japan are very complicated. The Senkaku Islands dispute and 2010 incident are presently one of the most important reasons for disagreement.

\section{NotA O AUTORZE}

Piotr Kaczmarek [pkk1988@wp.pl] - student II roku SUM na kierunku politologia. Stypendysta Ministra Nauki i Szkolnictwa Wyższego. Jego zainteresowania koncentrują się wokół rywalizacji mocarstw oraz aktywności międzynarodowej Chińskiej Republiki Ludowej i Stanów Zjednoczonych. 